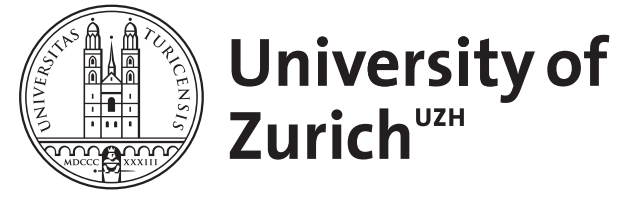

Zurich Open Repository and Archive

University of Zurich

University Library

Strickhofstrasse 39

CH-8057 Zurich

www.zora.uzh.ch

Year: 1999

\title{
Arbitrability and the applicable law in the claims resolution process for
} dormant accounts in Switzerland

Voser, $\mathrm{N}$

DOI: https://doi.org/10.1093/arbitration/15.3.237

Posted at the Zurich Open Repository and Archive, University of Zurich ZORA URL: https://doi.org/10.5167/uzh-153980

Journal Article

Published Version

Originally published at:

Voser, N (1999). Arbitrability and the applicable law in the claims resolution process for dormant accounts in Switzerland. Arbitration international, 15(3):237-266.

DOI: https://doi.org/10.1093/arbitration/15.3.237 


\title{
Arbitrability and the Applicable Law in the Claims Resolution Process for Dormant Accounts in Switzerland
}

\author{
by NATHALIE VOSER*
}

\section{INTRODUCTION}

THE CLAIMS Resolution Tribunal (CRT) ${ }^{1}$ has its seat in Zurich, and is an independent arbitral institution which was created by the Independent Claims Resolution Foundation, established pursuant to Articles 80 et seq. of the Swiss Civil Code in the autumn of 1997. Its purpose is to adjudicate claims to accounts which have been inactive ('dormant') since the end of World War II. The CRT is monitored by the Claims Resolution Foundation (which is in turn monitored by the Swiss Federal Banking Commission and the Independent Committee of Eminent Persons2). The Board of Trustees of the Claims Resolution Foundation was responsible for appointing the Chairman of the Tribunal, Professor Hans Michael Riemer, and 15 arbitrators. On 15 October 1997, the Board of Trustees adopted the Rules of Procedure for the Claims Resolution Process (RP) under which the CRT operates. ${ }^{3}$

The resolution of claims before the Claims Resolution Tribunal is - by its nature - intended to be an arbitration process. However, the CRT must deal with claims which are distinctively different from those which come up in 'ordinary'

Senior Associate, Schellenberg \& Haissly (Switzerland); part-time lecturer at the Faculties of Law of the Universities of Zurich and St. Gallen. This paper was presented at the ASA Conference on 22 January 1999, and a publication in an ASA Special Series is planned. The opinions in it reflect the author's view, which is not necessarily the view of the Claims Resolution Tribunal.

1 In the following, the term CRT is used for the whole tribunal, as such, as well as for the adjudicating bodies of the CRT, i.e. the Sole Arbitrators or the Claims Panels composed of three arbitrators (see Art. 3 RP).

2 On 2 May 1996, the Swiss Bankers Association and the World Jewish Restitution Organisation signed a Memorandum of Understanding which provided for the creation of The Independent Committee of Eminent Persons (ICEP). The ICEP is chaired by former Federal Reserve Chairman Paul Volcker.

3 For further details, see Hans Michael Riemer, Georg von Segesser and Brigitte von der Crone, 'Das Schiedsgericht für nachrichtenlose Konten in der Schweiz' (ASA 2/1998), p. 252 et seq. Amance DourthePerrot, 'Le tribunal arbitral pour les comptes en déshérence en Suisse' in (1999) 1 Rev. de l'Arb. at p. 21 et seq.

ARBITRATION INTERNATIONAL, Vol. 15 , No. 3

(C) LCIA, 1999 
international commercial arbitration. The differences can be summed up, by and large, by the following four points:

- the CRT must decide who the 'rightful owners of a published dormant account' are, i.e. the Tribunal must deal with issues of inheritance law; ${ }^{4}$

- in Ordinary Procedure (Article 14 RP), the CRT usually deals with more than one claimant, and the claimants often come from different jurisdictions;

- the CRT deals with triangle relationships always involving a Swiss bank, a (deceased) account holder, and at least one claimant;

- the death of the account holder may have occurred a long time ago, which can raise issues of transitory provisions of the applicable conflict-of-law and substantive law rules.

In light of the RP and the relevant provisions of Swiss law, the following paper will analyze the issues of arbitrability and applicable law under the above circumstances.

\section{THE QUESTION OF ARBITRABILITY}

\section{(a) Preliminary Remarks}

The relevant relationship in the Claims Resolution Process before the CRT is the relationship between the claimant(s) and the Swiss bank. This relationship is contractual in nature, ${ }^{5}$ since the claimant has entered into the position of a published account holder who has concluded a contract with a Swiss bank. ${ }^{6}$ The inheritance issue, i.e. the relationship between the claimant and the account holder, is only a preliminary question. Thus, there is no issue of arbitrability since it is generally accepted that preliminary issues in a contractual relationship are arbitrable. However, the Claims Resolution Process is - in reality - most often a dispute among several individuals each claiming to be the rightful heir, and not between the heirs and the bank. In some cases, the CRT will have to determine the validity of a will in order to render a decision on which of several heirs is entitled to the assets in the account with the Swiss bank. In these situations, the signed Claims Resolution Agreement (CRA) has an effect not only on the relationship between the claimants and the bank but - more importantly - on the

See Foreword to the RP.

Under Swiss substantive law, banking contracts are qualified as mandates, mandate-like contracts or bailment contracts. See Daniel Girsberger, Private International Law and Unclaimed Assets in Switzerland (Basel and Frankfurt am Main, Bibliothek zur Zeitschrift für Schweizerisches Recht 1997), Beiheft 23 at p. 51.

6 Under the civil law concept, the claimant becomes the rightful owner, based on succession, immediately after the account holder dies. This paper will not deal with issues of other types of ownership, such as beneficial ownership based on constructive trusts known in common law jurisdictions. In addition, no view will be expressed about the issue of other forms of entitlement (such as personal rights, i.e. obligations of the claimant towards the account holder) which, based on the open wording of the rules, might be considered a valid basis for a claim. 
relationship between the individual claimants. It is thus expected by each participating claimant that the award concerning entitlement based on inheritance considerations (including the validity of wills) rendered by the CRT will be binding upon each of the claimants.

Therefore, it appears questionable whether or not the fact that the CRT deals prima facie with a contractual relationship with the bank would, for example in the context of recognition of the award rendered by the CRT, be sufficient to establish the subject-matter arbitrability. The 'true' test should be whether or not the heirs could, in a dispute about entitlement concerning only themselves, submit this dispute to arbitration. The following sections (see $(b)$ and $(c)$ ) focus on this issue.

\section{(b) General Rule of Arbitrability}

In the 1980s, the question of arbitrability was one of the most difficult issues in international arbitration. ${ }^{7}$ Today, although the clouds have cleared, the difficulties are still significant, especially in the context of arbitrating disputes in areas with a strong public interest, such as unfair competition and anti-trust or securities exchange law. Additionally, areas in which a state authority participates in private disputes, such as in patent disputes, bankruptcy issues and non-contentious jurisdiction ('Freiwillige Gerichts-barkeit') are typically non-arbitrable. In these fields, the tendency is to allow arbitration wherever there is no clear mandatory exclusion in the lex arbitri. ${ }^{8}$ Finally, due to issues regarding possible injury to someone's person or reputation ('Schutz der Persönlichkeit'), the subject of arbitrability is also of special concern with regard to civil status and capacity, divorce or judicial separation, ${ }^{9}$ and labour law disputes, as well as - as with claims brought before the CRT - inheritance matters. ${ }^{10}$

The Swiss Private International Law Act (PILA) contains special substantive rules ('règle matérielle à caractère international' or 'IPR-Sachnorm') for the determination of the arbitrability of an issue before an arbitral tribunal that has its seat in Switzerland. Article 177 PILA has autonomously determined that 'any dispute involving an economic interest may be subject to an arbitration'. In doing so, the authors of the PILA rejected a solution based on a conflict-of-law rule which referred the arbitral tribunal to another law (such as the lex causae, or the law of the

7 See Botschaft des Bundesgesetzes zum Internationalen Privatrecht of 10 December 1982 (Publication 82.072) at p. 197. For a comparative analysis, see Publications of the $S_{w i s s}$ Institute of Comparative Law (Volume 11), Jurisdictional Problems in International Commercial Arbitration: A Study of Belgian, Dutch, English, French, Swedish, Swiss, U.S. and West German Law (1989).

8 So far, the relationships between the obligatory participation of state authorities and arbitration has not received much attention, but see Peter Schlosser, 'Schiedsgerichtsbarkeit und Freiwillige Gerichtsbarkeit', in Schiedsgerichtsbarkeit in gesellschaftsrechtlichen und erbrechtlichen Angelegenheiten, German Institute of Arbitration, Vol. 11 (1996) at pp. 97-111.

9 Article 2060 of the French Civil Code has expressly excluded these questions from arbitration. The same provision also contains a general rule excluding 'all fields which concern public policy' from arbitration.

10 Juno Huber, Die objektive Schiedsfähigkeit im Zusammenhang mit der Gültigkeit der Schiedsvereinbarung (anwendbares Recht) und mit der Vollstreckung (Order public) (1986) at pp. 117-118. 
seat of one of the parties involved, or the lex fori) in order to determine the arbitrability of the issue in question. ${ }^{11}$

Since any claim which will have a positive effect on the balance of the claimant's assets can be considered to involve an 'economic interest', it is generally recognized under Swiss international arbitration law that it is not only claims resulting from a contractual relationship or from tort that qualify as having an 'economic interest', but also claims based on family law, property and inheritance law. ${ }^{12 / 13}$

There is very little literature in Switzerland confirming that inheritance matters are arbitrable. It has never been disputed by legal commentators that heirs may agree to another forum for inheritance disputes. Based on this, it can be assumed that heirs can also agree to arbitration for actions for avoidance or reduction of testamentary disposition, as well as for the delivery of possessions or the allocation and distribution of an estate. ${ }^{14}$ It follows that for all PILA-governed claims between several claimants, the question of whether or not the claimant is entitled to the published account holder's assets with the Swiss bank based on inheritance law is in principle - arbitrable. This is also the case for claims which are governed by the Concordat. $^{15}$

11 With this rule, the PILA has abandoned the generally accepted principle that only disputes which may be compromised by the parties can be submitted to arbitration. This is, for example, the view in the Netherlands (see Article 1020 (3) of the Dutch Arbitration Act, which has been in force since 1986), and in Switzerland under the Concordat. See also Jurisdictional Problems, supra note 7, 127. The old German Arbitration Act was based on the same rule, but this has been changed in the revised German arbitration law, which has been in force since 1 January 1998. The German Act now uses the same criterion for the determination of arbitrability as in Art. 177 PILA (\$1030 para. 1 of the German Act on Civil Procedure, ZPO). However, it seems that prevailing opinion applies this criterion only to internal arbitration cases, whereas in internal situations it is the lex causae of the arbitral agreement which will determine whether or not a dispute is arbitrable (see Rolf A. Schütze, Schiedsgericht und Schiedsverfahren, (2nd ed. 1998) note 97). In the UNCITRAL Model Law (1985) the Commission took a very careful approach to the issue of arbitrability by adopting a provision which provides that the Model Law does not affect any other laws of the enacting state, by virtue of which certain disputes may not be submitted to arbitration. See Art. 5(1) UNCITRAL Model Law 1985. It was - at the time - considered impossible to provide an exhaustive list of non-arbitrable subject matters which could have formed the basis of a lex specialis in the Model Law. See Howard M. Holtzmann and Joseph E. Neuhaus, A Guide to the UNCITRAL Model Law on International Commercial Arbitration: Legislative History and Commentary (The Hague, 1989) at p. 39.

12 Robert Briner, Kommentar zum Schweizerischen Privatrecht - Internationales Privatrecht (1996) note 9, Art. 177.

13 Since the New York Convention (Convention on the Recognition and Enforcement of Foreign Arbitral Awards, New York, 10 June 1958) allows the recognition of an arbitral award to be denied if the disputed issue cannot be settled by arbitration under the law of the country where recognition and enforcement is sought, a substantive rule on the arbitrability of the issue under the lex arbitri bears the risk that an award may not be enforceable in another jurisdiction (Art. V 2(a) New York Convention). Because the courts of the recognizing states have also applied the distinction between domestic and international public policy to the question of the arbitrability of a given issue, the non-arbitrability of the issue has, in practice, led in only a few cases to a refusal of enforcement under the Convention. Albert Jan van den Berg, The New York Arbitration Convention of 1958 (1981, reprinted 1994) at pp. 369, 375.

14. See especially Thomas Rüde, Gültigkeit von Schiedsklauseln in letztwilligen Verfügungen, ASA Special Series No. 8 (1994), p. 146. Rüde refers to relevant cases of the Federal Supreme Court and Cantonal Courts.

15 Rüde, ibid. at p. 146. Some of the arbitration cases submitted to the CRT may not fall within the scope of the PILA, but may be governed by the Concordat of the Cantons on Arbitration. The practical impact of the Concordat is not very important: by the end of November 1998, 401 or 4.3 per cent of all the claims filed were submitted by claimants from Switzerland. Since not all these claims will pass the initial screening, the effective number of cases falling under the Concordat is even smaller. 


\section{(c) Limitations to the Arbitrability of Economic Interests}

Although the tendency is clearly to reduce the restrictions on arbitrability, some states still exclude arbitration by means of mandatory rules ('lois d'application immédiate') in areas such as anti-trust laws or stock exchange provisions. In addition to these areas, there is a whole range of provisions intended to protect the 'weaker party'. A classic example is the 1961 Belgian law on agency, ${ }^{16}$ and the rules excluding arbitration in employment contracts. ${ }^{17}$ Since inheritance issues concern a person's status, and since interested third parties might be involved as additional heirs who are not party to the proceedings before the CRT, their arbitrability may also be called into question. In the area of inheritance law, the law of the concerned states ${ }^{18}$ might, therefore, provide for (implicit or explicit) exclusive jurisdiction of their courts. ${ }^{19}$

In the Fincantieri-Cantieri Navali Italiani S.p.a. and Oto Melara S.p.A. v. M case, ${ }^{20}$ the Swiss Federal Supreme Court confirmed that Article 177 PILA contained an independent substantive rule for the determination of the arbitrability of a given issue. Thus, as a general rule, the arbitral tribunal in Switzerland does not have to consider third countries' mandatory rules on arbitrability. However, the decision also held that the arbitral tribunal had to consider the mandatory rules limiting or excluding arbitrability if the rules in question were of public policy character. ${ }^{21}$

Non-arbitrability based on the consideration of mandatory rules of concerned third states or on public policy reasons, as suggested by the Federal Supreme Court, would make an arbitral award appealable but not - or only in extremely limited circumstances - null and void. As a rule, it is up to a party to contest the arbitrability of the issue. ${ }^{22}$ The possibility that the CRT might, in practice, encounter problems of arbitrability can therefore be virtually excluded, even though the CRT does not operate under the usual circumstances of international commercial law.

16 See, for example, ICC Case No. 6379 of 1990 (1992) XVII Y B Comm. Arb. 212.

17 The arbitrability of employment contracts is not completely excluded under Article 343 of the Swiss Code of Obligations. However, the parties to an employment contract are excluded from agreeing in advance to arbitration. In other words, an arbitration agreement is only valid once the dispute has commenced. See $\$ 13$ para. 4 of the Law of Court Organization of the Canton of Zurich (GVG).

18 In claims before the arbitral tribunal, other concerned states are typically the states of the domicile of the claimant and/or of other heirs, and/or the state of the last domicile of the account holder.

19 This is especially the case where there is real estate located in that state. In this situation, it is questionable whether or not an arbitral tribunal with its seat in Switzerland would have jurisdiction, although more and more legal authors are of the opinion that public authorities, such as land registrars, should accept the arbitral tribunals' ruling and make entries in the land register as if these rulings had been made by state courts; see Schlosser, supra note 8 at p. 111. In Switzerland, Art. 86 para. 2 PILA provides that the Swiss courts must respect the exclusive jurisdiction of the courts of the state where real estate is located with regard to this property.

20 Decision of the Federal Supreme Court dated 23 June 1992 (BGE 118 II 353).

21 According to Briner this also follows from Art. 190 para. 2e PILA, which provides that an award can be set aside, where the award is incompatible with public policy; Briner, supra n. 12, notes 18 and 19, Art. 177.

22 Briner, supra n. 12, note 20, Art. 177. 
However, if a party to proceedings where multiple claims were filed for the same account were to claim non-arbitrability of the entitlement based on the mandatory provisions providing for exclusive jurisdiction of a concerned state, the CRT would then have to examine carefully whether or not this should lead to it declining jurisdiction. Given the general duty of any arbitral tribunal to make every effort to render awards which are enforceable, ${ }^{23}$ this question should be examined even if the parties do not put forward this argument, assuming that the CRT is aware of relevant mandatory provisions.

\section{THE CHOICE OF APPLICABLE LAW BY THE CRT IN THE ABSENCE OF A CHOICE OF LAW}

\section{(a) General Remarks}

If a claimant has accepted the resolution of his or her claim by means of the Claims Resolution Process by the CRT and has, for this purpose, signed the CRA, he or she is deemed to have accepted Article $16 \mathrm{RP}$ on the law applicable to the resolution of claims before the CRT.

Article 16 RP has very specific features: first, it makes a distinction between different relationships. There is a rule for the relationship between the account holder and the claimant on the one hand (see (b)), and for the relationship between the Swiss bank and the claimant on the other hand ${ }^{24}($ see $(c)$ ). Secondly, the RP does not explicitly provide for choice of law by the parties (see IV).

\section{(b) Relationship Between the Published Account Holder and the Claimant}

The relationship between the published account holder and the claimant is, in principle, based on the claimant's entitlement to the account holder's assets in Switzerland according to the applicable inheritance rules..$^{25}$ Although the claimant has an economic interest, which - as explained in the previous section - determines the issue of arbitrability, the relationship between the account holder and the claimant is a non-monetary, preliminary issue which must be addressed by the CRT.

This section will examine the basic principles of Article 16 paragraph 1 RP (see (i)), and will present the conflict-of-law solution in Switzerland and in some other jurisdictions (see (ii)), as well as in the Hague Convention on the Law Applicable to Succession to the Estates of Deceased Persons (see (iii)). Finally, to conclude the analysis, factors for the determination of 'closest connection', as provided for in Article 16 paragraph $1 \mathrm{RP}$, will be suggested.

\footnotetext{
23 See for example Art. 35 ICC Rules.

24 The claimant, by means of inheritance, enters into the position of the account holder.

25 See comments in $n$. 5 with regard to the issue of other bases of entitlement.
} 


\section{(i) The principles of Article 16 paragraph $1 \mathrm{RP}$}

\section{TWO-STEP PROCEDURE WITH CLOSEST CONNECTION TEST}

Article 16 paragraph $1 \mathrm{RP}$ provides that the relationship between the published account holder or the holder of the power of attorney on the one hand, and the claimant on the other, will be determined in accordance with the law to which the matter in dispute has the closest connection. In other words, the closest connection is the conflict-of-law rule which the CRT must apply in determining the applicable law. With this solution, which is identical to Article 187 PILA, the authors of the RP have adopted a two-step procedure. Most traditional two-step procedures, however, do not operate with the 'closest connection' rule, but give the arbitral tribunal the right to choose the conflict-of-law rule which it deems appropriate. ${ }^{26}$

It has been contended that the flexibility offered by the two-step procedure actually gives the arbitrator flexibility to no effect, as an arbitrator is given the freedom 'to choose the conflict-of-law-rule he likes best, but not the rule of substantive law he deems best suited to the occasion'. ${ }^{27}$ New national arbitration laws and institutional arbitration rules have taken this criticism into consideration and have consequently broadened the arbitrator's discretion by allowing him or her to choose the applicable substantive law directly. With this so-called 'voie directe', the arbitrator enjoys almost unlimited freedom in the choice of rules of substantive law. ${ }^{28}$

In situations as complex as those that are presented to the CRT, it might have been useful to build into the RP the same solution as that adopted in the newest institutional arbitration rules, i.e. to have given the CRT full discretion to choose the law which it deems appropriate. On the other hand, any choice must follow careful deliberation by the CRT, and the conflict-of-law rule of the closest connection can also be regarded as only indicating that the choice of a specific substantive law must be based on valid grounds.

Under Swiss conflict-of-law rules, the closest connection test, as provided for in Article $16 \mathrm{RP}$, is the basic rule for determining the law applicable to contracts. It is assumed that the closest connection exists with the state of the habitual residence

Art. 33 of the UNCITRAL Arbitration Rules of 1977 and Art. 28 of the UNCITRAL Model Law of 1985 embodied this method; this pattern was also followed by Art. 13.3 of the ICC Rules of 1988.

27 Hans Smit, 'The Future of International Commercial Arbitration: A Single Transnational Institution?' in (1986) 9 Colum. J Transnat' L 22 at p. 24. John R. Crook, 'Applicable Law in International Arbitration: The Iran-U.S. Claims Tribunal Experience' in (1989) $83 \mathrm{Am} . J$ Int'l L 278 at p. 285.

28 The 'voie direct' is, for example, embodied in the French Arbitration Law of 1981 and in Art. 59 of the Rules of the World Intellectual Property Organization (WIPO Rules) of 1994. The revised ICC Rules have also adopted this method, see Art. 17 para. 1 of the ICC Rules of 1998. The Rules of the American Arbitration Association (as amended and effective 1 April 1997) state that the "tribunal shall apply such law(s) or rules of law as it determines to be appropriate' (Art. 28(1) AAA Rules). Art. 22.3 (effective 1 January 1998) of the revised LCIA rules provides that if the parties have not made a choice of law, "the Arbitral Tribunal shall apply the law(s) or rules of law which it considers appropriate.' 
of the party who has to perform the characteristic obligation..$^{29}$ In addition - as already mentioned - the Swiss lex arbitri provides the same rule for determining the applicable law for arbitral tribunals with their seat in Switzerland, which - by definition - can only have jurisdiction over issues of economic interest. Both models clearly had commercial settings in mind; it is, in the author's opinion, questionable whether or not this model is well adapted to the issue of the choice of applicable law for inheritance matters which is, in the vast majority of cases, at stake with regard to the relationship between the published account holder and the claimant. On the other hand, if the authors of this rule intended to grant the CRT wide discretion, this goal has been reached. Based on the broad discretion granted it under Article $16 \mathrm{RP}$, the CRT can develop its own guidelines (see III(b)(iv) infra).

\section{RULES OF LAW VERSUS A NATIONAL LAW}

In commercial arbitration, the whole discussion surrounding lex mercatoria has led to a general acceptance that arbitral tribunals can apply 'rules of law' in lieu of a body of national law. The discussion concerning the rules of law has recently been encouraged by the publication in 1994 of the UNIDROIT Principles of International Commercial Trade. The unresolved question in scholarly work today is not whether or not an international arbitral tribunal can base its decision on ' $a$ national' or 'private' rules of law, but, rather, which rules qualify as rules of law and can thus form a valid basis for a decision. Recently revised institutional arbitration rules have reflected the tendency to apply rules of law, in that they do not provide for the application of a certain 'law', but expressly allow the arbitral tribunal to apply 'rules of law'. ${ }^{30}$

Under Article 187 PILA, which certainly influenced Article 16 paragraph 1 RP, it is not obvious at first sight whether or not the arbitral tribunal can - in the absence of a choice of law by the parties - base its decision on rules of law. Whereas the German and Italian texts of Article 187 PILA refer only to 'law', the French text includes the wording 'rules of law' ('règles de droit'). Based on the history of Article 187 PILA and on the French wording, it has been maintained that the application of 'general principles' is possible. ${ }^{31}$

It follows that it would have been preferable to allow explicitly for the application of 'rules of law'; in practice, however, this would not have made much of a difference, given the lack of a body of rules of law applicable to the question of inheritance matters. ${ }^{32}$ In addition, the CRT could take the view that, similarly to

Art. 117 PILA. The same nule is applicable within the scope of the Convention on the Law Applicable to Contractual Obligations of 19 June 1980 (the 'Rome Convention'), in accordance with Art. 4 para. 1 ' of the Rome Convention.

30 Art. 17 para. 1 of the ICC Rules of 1998; Art. 28(1) AAA Rules.

31 A. Karrer, Kommentar zum Schweizerischen Privatrecht - Intemationales Privatrecht (1996), note 49 and 70 , Art. 187.

32 Other than in commercial arbitration, it is difficult to imagine non-legislative substantive rules for the issue of entitlement based on inheritance which could qualify as rules of law without crossing the line of the CRT acting as amiable compositeur. On this issue sec IV (c). 
Article 187 PILA, the wording of Article 16 RP does not exclude the application of non-national rules of law, although the French translation of Article 16 $\mathrm{RP}$ does not contain the wording 'règles de droit'. ${ }^{33}$

(ii) Brief comparative analysis of conflict-of-law rules in inheritance matters

\section{PRELIMINARY COMMENTS}

The law applicable to the succession of a deceased person ('Erbstatut') will determine all questions relating to circumstances surrounding a special estate being created because of the death of a person ('Erbfall'). This encompasses questions such as:

- statutory heirs;

- unworthiness to inherit;

- voluntary renunciation of the inheritance estate;

- how the transfer of the estate should take place (especially whether or not the transfer should take place automatically or whether a special act is necessary);

- relationship among several heirs;

- compulsory portions; and

- liability of heirs for obligations against the estate ('Nachlassverbindlichkeiten').

The basic conflict which has generally determined the discussion in international private law for many decades also distinguishes the conflict-of-law solutions in inheritance matters. This is the conflict between the principle of nationality ('Staatsangehörigkeitsprinzip') and the principle of domicile ('Domizilprinzip'). ${ }^{34}$ Whereas the general trend in continental European conflict-of-law rulings has been towards the principle of domicile, and even the 'habitual residence' in contractual relationships and tort cases and in the area of a person's status ('Statutsfragen'), both principles are still strongly represented. In practice, this means that the relevant factor for the law applicable to the estate ('Erbstatut') is either determined according to the nationality, or to the domicile or habitual residence of the deceased. Similarly to the conflict-of-law solutions in other legal relationships, there has been a trend, in international conflict-of-law, with regard to inheritance issues, towards applying the law of the last domicile instead of the law of the nationality of the deceased. ${ }^{35}$

The 'closest connection' test, as provided for in Article $16 \mathrm{RP}$, does not answer the question of which of the two principles is relevant to determining the applicable law. In applying this test, the CRT must find a 'just' solution between the two

33 The translation does not have a binding effect; see Art. 35 para. 2 RP.

34 Tim Brandi, Das Haager Abkommen von 1989 über das auf die Erbfolge anzuwendende Recht (Berlin, 1996) at p. 35.

35 Murad Ferid, Internationales Erbrecht, Vols. I-VII, at Vol. I (delivery XI, 1997), Einführung n. 43. 
conflicting principles, either by using general guidelines (see below $(b)(i v))$, or on a case-by-case basis.

Apart from the conflicting principles of nationality and domicile, the other main problem in the conflict of laws in inheritance issues is how to co-ordinate the approaches of the different jurisdictions with regard to the issue of the 'division of the succession estate' ('Nachlassspaltung'). A division of the estate occurs most often when the common-law jurisdictions apply the lex rei sitae to immovable assets, and the law of the last domicile of the deceased to the estate's movable assets. ${ }^{36}$ The CRT does not deal directly with the issue of division of the estate, since the assets of the published account holders with the Swiss banks are of a movable nature.

\section{THE SOLUTION OF THE SWISS CONFLICT-OF-LAW RULES}

The account holder must - as a rule - have been at least 20 years old when he or she opened a bank account in Switzerland. At the same time, the CRT only has jurisdiction for accounts which have been dormant since 9 May 1945 (Article 1(i) RP), which makes it likely that the account holder - even if not a victim of the war - probably died a long time ago. The inheritance issues with which the CRT is faced therefore quite often have intertemporal aspects. According to the Swiss intertemporal conflict-of-law rules, facts and legal acts which occurred before the new conflict-of-law rules came into force are governed by the law previously in force. ${ }^{37}$ Under Swiss succession law, the transfer of property to the heir occurs immediately at the time of death and the legal effect of the transfer is complete. Therefore, in cases where the death occurs prior to 1989, a Swiss court would apply the conflict-of-law rules that were in effect before the enactment of the PILA in January 1989.

Before the enactment of the PILA, Switzerland followed a 'mixed system' for determining the law applicable to succession: according to Article 22 of the Federal Law on the Civil Status of Persons Domiciled and Present (NAG), ${ }^{38}$ the law applicable to succession was that in effect at the last domicile of the deceased. This rule did not apply to foreigners with their last domicile outside Switzerland, ${ }^{39}$ only to persons who died in Switzerland, and who had their domicile in Switzerland in accordance with the rules of Article 23 of the Swiss Civil Code (CC). For persons who died outside Switzerland, case law relied on the law (including the relevant conflict-of-law rules) of the country of which the deceased was a national. ${ }^{40}$

36 Anton K. Schnyder, Kommentar zum Schweizerischen Privatrecht - Internationales Privatrecht (1996) note 38, Art. 91. For a precise definition of the term 'Nachlassspaltung', see Eva Maria Derstadt, Die Notwendigkeit der Anpassung bei der Nachlassspaltung im internationalen Frbrecht, (Baden-Baden, 1998) at p. 27.

37 Art. 196 para. 1 PILA. Girsberger, supra n. 5 at p. 53.

38 'Bundesgesetz betreffend die zivilrechtlichen Verhältnisse der Niedergelassenen und Aufenthalter' of 25 June 1891/10 December 1907/30 June 1973.

39 W. Stauffer, Praxis zum NAG (1975) at p. 73.

40 Stauffer, ibid. at p. 75. 
Article 90 PILA has not changed the conflict-of-law rules for persons with their last domicile in Switzerland, and states that the succession of a person who had his or her last domicile in Switzerland is governed by Swiss law. With regard to persons who died abroad, Article 91 of the PILA has not brought about any radical change since it still determines the governing law by declaring foreign systems of conflict-of-law rules to be applicable. In contrast to the NAG, the connecting factor is now the domicile of the deceased, and not their nationality, ${ }^{41}$ which reflects the general trend in international conflict of laws mentioned above. The so-called 'renvoi' in Article 91 PILA can lead back to Swiss law or to a third law, depending on whether or not the renvoi is considered to be limited to the substantive laws of the state to which the conflict-of-law rules of the state of the person's last domicile refer. There is a tendency in legal work to favour the 'foreign court theory': this means that a Swiss court will apply the law which would be applied if the 'foreign court', (according to Article 91 PILA, the courts of the state in which the deceased account holder had his or her last domicile) had to decide the case directly. ${ }^{42 / 43}$

In both cases (where the applicable law is determined in accordance with the PILA and in accordance with the old NAG regime), the question of whether the old law, which was in force at the time of the account holder's death, or an amended law applies is to be determined by the intertemporal rules of the applicable law. ${ }^{44}$

OTHER JURISDICTIONS

The prevailing rule in Continental Europe is (still) to apply the law (including the conflict-of-law rules) of the state of which the deceased is a national; referral back (i.e. a 'renvoi'), or to a third law must be taken into account. This is the case in Germany, ${ }^{45}$ in Italy's recently enacted international private code, ${ }^{46}$ and in

41 Art. 91 para. 1 PILA.

42 Schnyder, supra n. 36, note 6, Art. 91. Hans Kuhn, Der Renvoi im internationalen Erbrecht der Schweiz, Schweizer Studien zum internationalen Recht, Bd. 107 (1998) at p. 87. This solution is problematic if the foreign law also applies the 'foreign-court' theory. To avoid an ongoing backwards-and-forwards referral, the PILA accepts the renvoi or referral to a third law as a referral only to the substantive law. Another solution would be to apply the rule of the last domicile (as in Art. 90 PILA) for such situations; see Schnyder, supra n. 36 , note 6 , Art. 91 .

43 As has been pointed out by Walder, one cannot expect that the conflict-of-law rules of the account holder's last domicile provide for a renvoi to Swiss law only because the account holder (and now the heirs) had contractual obligations against a Swiss bank, or because movable assets are located in Switzerland. See Hans Ulrich Walder 'Rechtliches zur Frage der nachrichtenlosen Vermögenswerte auf Schweizer Banken', in (1997) SJZ 93 at p. 132.

44 Since some states - in particular those of Eastern Europe - have amended their succession law and their conflict-of-law rules after World War II, the issue of the foreign law's intertemporal rules could arise quite often; Girsberger, supra n. 5 at p. 65.

45 See Art. 25 EGBGB. In certain cases, based on Art. 3 para. 3 EBGBG, the lex rei sitae prevails over the application of the law of nationality. Kuhn, supra n. 42 at pp. 97-99; Schnyder, supra n. 36, note 34, Art. 90.

46 The new law 218/95, which entered in force on 1 October 1995, contains the relevant rule in Art. 46 para. 1 , see Kuhn, supra n. 42, at pp. 201/202. 
Austria by means of reference to 'personal status' ${ }^{47}$ Spain, ${ }^{48}$ Portugal ${ }^{49}$ and Greece $^{50}$ also still refer to the law of the state of which the deceased was a national. In Continental Europe, the states which do not follow the principle of nationality are, as explained above, Switzerland, the Netherlands, France and Belgium.

Until recently, however, the Netherlands did apply the principle of nationality. On 26 September 1996, the Netherlands ratified the Hague 'Convention on the Law Applicable to Succession to the Estates of Deceased Persons' ('Convention', see below, section iii); since this date, the Convention has been the law applicable to succession, following an autonomous enactment by the Netherlands based on the fact that it is uncertain if and when the Convention will enter into force. ${ }^{51}$

As of the last century, France has applied the law of domicile to movable assets within the estate. Until 1939, however, it was a matter of dispute whether the relevant domicile was the domicile de fait or the domicile de droit which, for foreigners, required an authorization. In 1939, in the Labedan ${ }^{52}$ decision, the Cour de Cassation decided that the relevant domicile was the domicile de fait. Immovable property is covered by the lex rei sitae. ${ }^{53}$

In Belgium, the prevailing solution is to apply the lex rei sitae to immovable property and the lex domicilii to movable assets. ${ }^{54}$ The relevant domicile is defined as the 'principal établissement'. This is where the deceased had his or her 'emotional and familial centre of interest'. ${ }^{5}$

In Israel, the Succession Law of 1965 provides for the application of the principle of domicile. ${ }^{56}$ Most other states in the Near East (such as Iran) follow the principle of nationality. The same applies for the Far East (as, for example, Japan and China). .57

Similarly to the situation in France, the principle of last domicile (as opposed to nationality) is the rule in England and the USA, though it applies only to movable

$\$ 28$ s. 1 Austrian Conflict of Laws; see Kuhn, supra n. 42 at p. 136 et seq. and 150 et seq.; Schnyder, supra n. 36 , note 37, Art. 90. Based on the jurisdictional rule, the estate of the deceased can be split with regard to real estate located outside Austria and for the movable assets of foreigners not located in Austria, Kuhn, supra n. 42 at p. 137.

48

Art. 9 s. 8 of the Código civil of 1889 . In Spain, there is the additional difficulty that different regional inheritance laws are in force. Arts. 13 to 16 (especially 14) determine the applicability of the regional laws; see Ferid, supra n. 35, Spain Grundzüge note 1.

Ferid, supra n. 35, Finführung notes 43 and 53

Kuhn, supra n. 42 at p. 235.

ibid. at p. 327 et seq.

Cass. Civ. 19.6.1939 481.

Kuhn, supra n. 42 at p. 255 et seq.

54 Rigaux/Fallon, Droit International Privé, Vol. 2, Droit positif belge (1993) note 1458; Ferid, supra n. 35, Country Report on Belgium, Grdz C note 5.

55 The fact that a person was living in Belgium before he or she died might, therefore, not be sufficient to establish domicile in accordance with the relevant Belgian law; Rigaux/Fallon, supra n. 54 at 1460.

56 Art. 137 of the Succession Law of 1965. Assets located abroad over which the foreign law has exclusive jurisdiction are exempted from the general rule (Art. 139 of the Succession Law). This exception applies primarily to real estate.

57 Ferid, supra n. 35 , note 43 Einführung. 
property. ${ }^{58}$ It must, however, be noted that 'domicile' has a different meaning in England than in Continental European states.

The situation in Latin America is complex, since the states use different connecting factors such as location, domicile and nationality as a basis for their unilateral conflict-of-law rules, which determine only the application of the lex fori. ${ }^{59}$

(iii) The Hague Convention on the Law Applicable to Succession to the Estates of Deceased Persons

\section{BACKGROUND}

On 19 October 1988, the 16 th Hague Conference adopted the 'Convention on the Law Applicable to Succession to the Estates of Deceased Persons'. The first signatory state was Switzerland, which signed the Convention on 1 August 1989. Luxemburg and Argentina have also signed the Convention, as has the Netherlands - as already mentioned - ratifying it as of 26 September $1996 .{ }^{60}$ It is, therefore, unclear whether or not the Convention will ever come into force since, according to Article 28 paragraph 1 of the Convention, this would require the ratification of at least three signatory states.

Reactions to the Convention were mixed, both in Europe (especially Germany) and in the United States. ${ }^{61}$ It is, however, noteworthy that the Advisory Committee on Private International Law, along with the US Secretary of State, decided in 1992 to recommend ratification by the United States. ${ }^{62}$ It follows that the United States may ratify the Convention, even though the reaction of conflict-of-law scholars was mixed. ${ }^{63}$

THE BASIC RULES ON THE QUESTION OF APPLICABLE LAW

The preparatory work for this provision was long and complicated, and some aspects of the basic rules on the applicable law were heavily disputed until the very end ${ }^{64}$ The provision that was finally adopted to deal with the applicable law in the absence of a choice of law (Article 3 of the Convention) provides as follows:

(1) Succession is governed by the law of the State in which the deceased at the time of his death was habitually resident, if he was then a national of that State.

(2) Succession is also governed by the law of the State in which the deceased at the time of his death was habitually resident if he had been resident there for a period of no less than five years immediately preceding his death. However, in exceptional circumstances, if at the time of his death he was manifestly more closely connected with the State of which he was then a national, the law of that State applies.

(3) In other cases succession is governed by the law of the State of which at the time of his death the deceased was a national, unless at the time the deceased was more closely connected with another State, in which the case the law of the latter State applies.

Schnyder, supra n. 36 , note 38 , Art. 90.

Ferid, supra n. 35, Einführung note 45.

This reflects the situation as of 17 November 1998.

For a comprehensive overview of legal opinion, see Brandi, supra n. 34, at p. 34.

Brandi, supra n. 34 at p. 34.

See ibid. footnote 48 for a list of opinions.

For details, see Brandi, ibid. at p. 91 et seq. 
This provision has three main objectives in mind: first, it should represent an acceptable compromise between the systems of domicile and nationality; secondly, it seeks a middle ground between the advantages of a flexible solution versus a solution which guarantees a predictable outcome; thirdly, the authors wanted to find a solution which respected a person's 'centre of life' ('Lebens-mittelpunkt') ${ }^{65}$

THE HABITUAL RESIDENCE

The term 'habitual residence' is open to various interpretations in different states, since it is not defined in the Convention itself. It is accepted that the court should make an autonomous interpretation regarding a person's habitual residence. ${ }^{66}$ The concept of 'habitual residence' has been used so often as a basic principle in different Hague Conventions that its interpretation is subject to precise guidelines. ${ }^{67}$

The first requirement is for a person's presence at the place in question for a 'certain time' before their death occurred. There is no fixed length of time, but using case law as a guideline suggests that a presence of six months meets this requirement. ${ }^{68}$ The question of whether or not a person needs to have a regular physical presence at a certain place to fulfil the criteria of 'habitual residence' has not found a unanimous answer. Some authors emphasize a person's subjective relationship to a certain place and, therefore, consider their regular presence there to be un-important. From the history of the provision of Article 3(2) of the Convention, one must, however, assume that the authors of this provision expected, as a second requirement, a person's habitual residence to be at the place where he or she was physically present most of the time, and not where he or she had the closest personal or familial relation-ships. ${ }^{69}$ Nevertheless, and most importantly, the 'habitual residence', as defined by the Convention, requires, thirdly, that a person have their centre of social and personal relationships at the habitual residence. In cases of divergence between a person's 'professional' and a 'private or social' centre, more emphasis is put on the social than the professional relationships. ${ }^{70}$

The concept of habitual residence does not require that a person should have he intention to remain permanently at the place of habitual residence. It is not,

65 Brandi, supra n. 34 at p. 98.

66 ibid. at p. 108. It follows that the interpretation of the habitual residence, as defined by Art. 20 PILA, is not decisive. Catherine Christen-Westenberg, Kommentar zum Schweizerischen Privatrecht - Internationales Privatrecht (1996) note 27, Art. 20.

67 For the following see Brandi, supra note 34 at p. 109 et seq. For the interpretation of the habitual residence under the Hague Conventions see Marco Levante's recent study, Wohnsitz und gewöhnlicher Aufenthalt im internationalen Privat- und Zivilprozessrecht der Schweiz (St. Gallen 1998) at p. 78 et seq.

68 Levante, ibid. at p. 84 .

69 Brandi, supra n. 34 at p. 112.

70 ibid. at p. 113. 
therefore, necessary to analyze whether a deceased person had any such intent if their physical presence and their centre of social relationships can be determined. ${ }^{71}$

\section{(iv) Conclusion: interpretation of the 'closest connection' in Article 16 paragraph $1 R P$}

\section{BASIC PRINCIPLES}

The above brief overview of the conflict-of-law rules has shown that, in order to determine the law applicable to succession, the rules always involve a solution based on analysis of the deceased person's situation at the time when their death occurred. Although the wording of Article 16 RP states that the closest connection to the 'matter in dispute' shall determine the applicable law, this determination must be made based on the account holder's situation at the time of his or her death. Based on this result, the interpretation of Article 16 paragraph 1 RP leads to the conclusion that the relationship between the published account holder (or the holder of a power of attorney) on the one hand, and the claimant on the other, should be determined in accordance with the law of the state to which the account holder had the closest connection at the time of his or her death. In view of the existing conflict-of-law rules, it cannot be assumed that the closest connection test leads to the application of Swiss inheritance law only because the account holder established contractual obligations towards a Swiss bank, or because movable assets of the account holder's heirs are located in Switzerland..$^{72}$

If the account holder's direct heirs are already deceased, the process of determining the applicable law must be carried out twice in order to determine the next generation's rights to the original estate of the account holder, i.e. to the assets located with the Swiss banks. The following analysis will focus on the account holder and his or her direct descendants; it should be understood that the same principles apply by analogy to determine the inheritance rights for any future generations.

The fact that the relevant connecting factors are determined based on the situation of the account holder and already deceased direct heirs, and not on the situation of (multiple) claimants to an account, obviates the need to consider more than one law for one estate. ${ }^{73}$ This would not be the case if the factors were

71 ibid. at p. 114. Art. 20 para. 1 s. b PILA provides for the definition of the habitual residence for Swiss conflict of laws. Although this provision was influenced by the Hague conventions, the criteria are not identical. The Swiss concept focuses more on the length of time of the residence, and does not require that the centre of a person's life be established directly, since this can be deducted from a person's length of residence. Levante, supra note 67 at pp. 105/106.

72 See Walder, supra n. 43 at p. 132.

73 The estate of the account has most often been split by virtue of the existence of several direct heirs. If those heirs survived World War II and lived in different states, the inheritance laws of each of those states must be applied to each of the 'new' estates of the deceased direct heirs of the account holder in order to determine the inheritance rights of claimants who claim to be entitled to the account based on being heirs of one of the several direct heirs of the published account holder. 
determined on the basis of the claimants' situation, rather than on the basis of the account holder's situation. ${ }^{74}$

The difficulties which might arise from the early death of the account holder would cause substantial problems to state courts which might have to consider old conflict-of-law rules of the lex fori as well as old conflict-of-law rules and substantive laws of foreign states. For an arbitral tribunal, the situation is clearly different: based on the closest connection test, as provided for in Article 16 paragraph $1 \mathrm{RP}$, the CRT does not face such problems, since the closest connection factors can be determined independently from any conflict-of-law rule, and thus also independently from the transitory provisions of foreign conflict of laws or substantive law. However, the fact that a person died a long time ago can have an influence in determining the factors for closest connection which should, to a certain degree, take into account the law of the 'connected' jurisdictions at the time when the death of the account holder occurred.

There are good reasons why the CRT should adopt the principles of Article 3 of the Hague Convention as its own guidelines:

(1) The overview of the conflict of laws in other jurisdictions has revealed a gap between states which follow the principle of nationality, and states which adopt the principle of domicile. The authors of the Hague Convention have tried to find a viable compromise between these two principles. Such a compromise could facilitate the acceptance of CRT awards by claimants living in states with one principle when the account holder died in a state where another principle applied.$^{75} \mathrm{~A}$ compromise is even more necessary if there are multiple claimants who live in different states, each of which represents a different principle (for example Germany and the United States).

(2) The strict principle of nationality does not represent the current thinking in conflict of laws, since it does not reflect a person's centre of social and economic relationships; in a world of constant migration, this principle is no longer justified.

(3) Finally, by relying on the concept of 'habitual residence' rather than 'domicile', the Hague Convention avoids difficulties caused by the fact that the meaning of the term 'domicile' can vary considerably from jurisdiction to jurisdiction.

74 Conversely, this means that claimants from different jurisdictions must - as a rule - accept the fact that the arbitral tribunal will not consider their laws. However, claimants may enter into settlement agreement with the banks or allow the CRT to base its decision on ex aequo et bono (see IV (c)) if they are aiming at an outcome which would be more familiar to them.

75 By the end of November 1998, Atag Ernst \& Young had received approximately 21 per cent claims from claimants from the US, 12 per cent from Germany, 11 per cent from France, and 9.5 per cent from Israel. In the US and France the principle of domicile prevails for movable assets, whereas in Germany and Israel the claimants would expect the CRT to apply the law of the nationality of the deceased account holder. 
There are also, however, important reasons why CRT should not rely on the Convention as a guideline: one could very well argue that there is no reason for the CRT to apply a (partly political) compromise instead of determining the applicable law on a case-by-case basis. More importantly, the Convention, which was only adopted in 1988, does not take into account the fact that the account holders might have died a long time ago, and may even be victims of the Holocaust. ${ }^{76}$ For these cases, applying the rules of the Convention as a matter of principle would not be justifiable, since this would not respect the fact that the account holders died a long time ago under special and unforeseen circumstances. The account holder's expectations would inevitably have been influenced by the situation as it then stood, and this should outweigh the claimants' expectations to have rules of law applied which are current and more familiar to them.

Although it is difficult to categorize the claims, since each one has a different and unique background, it follows from the above that the CRT should, in the author's opinion, distinguish between three basic categories of account holders in order to determine the applicable law:

(1) The first category encompasses claims to accounts of account holders who neither died as victims of World War II, nor had to flee because of World War II.

(2) In the second category, the account holders did not die during World War II, but had to flee (i.e. were refugees in a strict sense), or emigrated to another state as a consequence of World War II or the political conditions which preceded it.

(3) The third category includes war victims, i.e. those account holders who died as a direct result of the Holocaust (especially after deportation) or otherwise in connection with the persecutions of World War II, for example, while fleeing. The main determining factor for this category would be the account holder's death having occurred during World War II, i.e. between 1 September $1939^{77}$ and 9 May 1945.

FIRST CATEGORY: ACCOUNT HOLDERS WHO NEITHER DIED AS A DIRECT CONSEQUENCE OF WORLD WAR II NOR LEFT THEIR HOME STATE BECAUSE OF WORLD WAR II

For these claims, the advantages of applying the Convention to determine the applicable law to the account holder-claimant relationship outweigh the abovementioned disadvantages. Where one body such as the CRT has to deal with so many jurisdictions, it is appropriate to apply the solution which was reached by the delegations in the 16th Hague Convention in 1988 even though it constitutes a

76 Judging by the CRT's experience through November 1998, 10 to 20 per cent of the cases have a Holocaust connection; see NZZ of 19 November 1998 at p. 2.

77 Invasion of Danzig (Poland) by the German army. In order to take into account the racial and religious persecutions that took place before the beginning of World War II, any death that occurred after the 'Reichskristallnacht' on 9/10 November 1938 counts as falling within this category. 
compromise, having only been signed by four states and ratified by one. The Convention itself allows for adaptation to individual cases by means of exceptions. The fact that the account holders have frequently died long before 1988 is not taken into account does not hinder using the rules of the Convention, as the 'closest connection' test allows consideration of factors other than when and where the account holder died.

As a consequence, the following rules apply for the first category of account holders:

- rule 1: the law of the state of habitual residence of the account holder will apply if he or she was resident there for a period of more than five years immediately preceding his or her death; however, in exceptional circumstances, and if at the time of the account holder's death he or she was manifestly more closely connected with the state of which he or she was then a national, the law of that state will apply (exception 1);

- rule 2: the applicable law is the law of the state of habitual residence at the time of death if the habitual residence was for less than five years, and if the account holder is a national of this state (as a rule, habitual residence requires that a person be present in a state for at least six months);

- rule 3: in other cases, the law of nationality will apply, unless, at the time of death, the account holder was more closely connected with another state, in which case the law of the latter applies (exception 2).

At first sight, it is difficult to see when exception 1 could become relevant, since the closest connection and the criteria for the determination of habitual residence have the same function, i.e. establishing a person's centre of social and personal relationships at a given location. However, based on specific examples which were brought up by the British delegation in the 16th Hague Conference, ${ }^{78}$ exception 1 could become relevant if the account holder had, first, the intent to leave his or her habitual residence at a fixed time in the future, or, secondly, if he or she was not socially integrated at his or her place of habitual residence, or, thirdly, if he or she had ongoing close family and personal ties to the state of his or her nationality. The criteria of 'exceptional circumstances' and the 'manifestly' closer connection indicate that the exception should be applied restrictively.

Exception 2 is more straightforward. The authors of the Hague Convention had the situation of immigrants in mind. Immigrants often bring their whole family with them and do not intend - as a rule - to return to their state of origin. The

78 The examples were:

(1) Retired British persons living in the Canary Islands and the Balearic Islands who only have social contact with persons from England, and wish to spend the rest of their lives there.

(2) An engineer who had a fixed contract in a foreign state for three years but whose contract was then extended for another three years.

See Brandi, supra n. 34 at pp. $117 / 118$. 
participants of the Hague Conference did not consider it justifiable to have the immigrants' succession governed by the law of their nationality. ${ }^{79}$

SECOND CATEGORY: REFUGEES AND EMIGRATION AS A CONSEQUENCE OF WORLD WAR II

For the reasons mentioned above, the Convention can be used as a guideline for the interpretation of 'closest connection' for this second category of account holders. However, the exceptions must be applied in order to take into account the special circumstances of World War II when determining the applicable law under Article 16 RP.

For individuals who had to flee from Germany, or from an occupied state, before or during World War II, and who would, under the applicable conventions, count as refugees, there are two possible scenarios.

On the one hand, the concept of habitual residence is based on a person having 'free' choice regarding where they wish to live. If a person's presence at a given location occurred against their will, then no relevant habitual residence can be assumed.$^{80}$ It would, therefore, seem justifiable to apply exception 1 . The relevant five-year period should begin after the end of World War II, and the law at the new habitual residence would then apply from 9 May 1950 onwards. Before this date, succession would fall, as a rule, under the law of the nationality of the deceased. ${ }^{81}$

On the other hand, a person could have chosen to leave their home country in order to make a conscious and intentional break with the past. This was probably most often the case if emigration took place in the years before the outbreak of World War II, as a consequence of the racial and religious discrimination during that time. If the account holder emigrated after the war was officially over, i.e. after 9 May 1945, it can again be assumed that his or her leaving the home country was not a temporary move, since there was usually no intention to return. This was basically the setting which the members of the 16th Hague Conference had in mind when they created the exception to the rule of nationality in Article 3(3) of the Convention (exception 2). For refugees, this would correspond to Article 12.I of the 1951 Convention Relating to the Status of Refugees and Article 12.I of the Convention Relating to the Status of Stateless Persons of 1954: both conventions state that the relevant connecting factor for the determination of a personal relationship, to which the inheritance issue belongs, is not nationality but domicile. ${ }^{82}$ It would seem unfair not to apply the law applicable at the new habitual residence to refugees who had renounced their home states, but who had still not been released from their old nationality before the five-year period had elapsed.

\footnotetext{
ibid. at p. 123.

ibid. at p. 115 .

If, at the time of their death, the deceased had the nationality of the state of immigration, this state's law applies (rule 2).

82 According to the leading view in Germany, domicile should be understood in the sense of 'habitual residence' in order to allow a consistent application of the conventions; Jan Kropholler, Internationales Privatrecht (1997) at p. 246.
} 
This second argument prevails and, as a result, exception 2 should apply to emigrants and refugees. The succession of account holders who emigrated or fled before, during or in the aftermath of the war and died before the five years had elapsed should, as a rule, therefore be governed by the law in effect at their new place of habitual residence. In exceptional circumstances (if they intended to return to their home country and/or if all the rest of the family remained there; if the account holder basically waited until the war was over to return to his or her home country), there might be justification for applying exception 1 after the fiveyear period had elapsed, and for basing succession on the nationality of the account holder.

THIRD CATEGORY: WAR VICTIMS

The succession of account holders who died as a direct consequence of World War II is most closely connected to their nationality at the time of their death. As already mentioned, ${ }^{83}$ it would seem inappropriate to apply a more modern connecting factor, such as habitual residence, to situations that date from long before this concept was widely known. Therefore, the succession should fall under the law which would have been applied in the state where the account holder died at the time of his or her death. ${ }^{84}$

There is, naturally, only limited data available on the published account holders. However, the account holders indicated their country of domicile in the banking documents and this has been, to a large extent, reported by the banks to Atag Ernst \& Young. ${ }^{85}$ Based on this data, the most frequent domiciles of account holders, with regard to claims filed by November 1998, were France (approximately 20 per cent), Germany (18 per cent), Switzerland and Austria ( 7 per cent), Romania, the United States, Czechoslovakia, Hungary, Poland, Italy and England (all with approximately 2 to 4 per cent).

Since, at the time of World War II, almost all Continental European states referred to the law of nationality, ${ }^{86}$ this leads to the law of the account holder's nationality at the time of his or her death being applicable. ${ }^{87}$ If an account holder died in France, having had his or her domicile de fait, in accordance with French law, in France, but having another nationality at the time that his or her death occurred, then the French law of domicile should apply to his or her movable

83 See supra III (b) (iv) - Basic Principles.

84 This conclusion has been reached based on the closest connection test, as provided for in Art. 16 RP. As explained above (see III (b) (ii) - The solution of Swiss conlict-of-law rules), the application of the principles of Swiss intertemporal conflict-of-law rules leads to the application of the previous conflict-of-law system in Switzerland, i.e. the NAG. This means that a Swiss court would also apply the law of the nationality of a person deceased outside Switzerland before 1989 .

85 The Swiss banks participating in the Claims Resolution Process reported the information on the Dormant Accounts which were found, as well as on the account holders, to Atag Ernst \& Young. This formed the basis of the two lists of dormant accounts which were published in 1997.

86 See supra III (b) (ii) - Other jurisdictions.

87 In cases of multiple nationality of the account holder, the CRT is justified in applying Art. 23 para. 2 PILA analogously and in submitting the succession to the law of the nationality of the state to which the account holder had the closest connection. 
assets in Switzerland, and not his or her law of nationality. The same applies to account holders who died as a result of the war and had their last domicile in Belgium but were not of Belgian nationality, since Belgian law applies the lex domicilii and not the law of the nationality. ${ }^{8} 8$

Kropholler has correctly pointed out how absurd it would be to make the succession of a person who died in a concentration camp dependent on which part of Poland the concentration camp was located in (i.e. the Polish, Austrian or Prussian part), and on which law was effectively in place during German occupation. ${ }^{89}$ It follows that, with regard to the above-mentioned place of the account holder's death, it must be assumed that this was the state where he or she lived before deportation, and not where the concentration camp was located. Therefore, it is not necessary to know in which concentration camp a war victim died or whether this was on the way to a concentration camp. This rule should also apply to account holders who were not killed in concentration camps or on the way to a camp, but while trying to escape from Germany or another occupied country, or who were killed as a direct result of the war at an unknown place.

\section{(v) Limitation to the applicable law?}

Under Swiss law, the question of whether or not an arbitral tribunal with its seat in Switzerland must apply foreign mandatory rules, as required under Article 19 PILA, ${ }^{90}$ is a matter of dispute. Prevalent legal opinion correctly denies the arbitrator's obligation to consider foreign mandatory rules directly based on Article 19 PILA. ${ }^{91}$ At the same time, more and more authors have suggested that a third state's mandatory rules must nevertheless be taken into account and have developed guidelines for their 'application'. ${ }^{92}$ The issue facing the CRT is, therefore, whether or not (after determining the applicable law in accordance with the

88 See III (b) (ii) - Other jurisdictions.

89 Kropholler, supra n. 82 at p. 265.

90 For an overview of scholarly opinion in Switzerland, see Karrer, supra n. 31, note 1624, Art. 187; and Daniel Hochstrasser, 'Choice of Law and "Foreign" Mandatory Rules in International Arbitration' in (1994) $11 \mathrm{~J}$ Int'l. Arb. 60 at p. 64. See also François Knoepfler, 'L'article 19 LDIP est-il adapté à l'arbitrage international?' in (1993) Études de droit international en l'honneur de Pierre Lalive at pp. 531, 533 et seq.; Anton Heini, 'Kommentar zum Schweizerischen IPRG' (1993) at 1588.

91 It is generally recognized today that an arbitral tribunal has to consider the lex arbitri, but does not have a lex fori in the same sense as a court does. Article 19 PILA is part of the Swiss lex fori, but was most likely not intended to also be part of the lex arbitri. For the same reason, i.e. due to the lack of a lex fori, Art. 19 PILA cannot have a direct and unmodified application, since questions on the application of foreign laws are based on the Swiss conception of law which would - from the point of view of an arbitral tribunal - put Swiss law in an unjustifiably prominent position.

92 In recent work, some guidelines have been suggested (see Marc Blessing, 'Choice of Substantive Law in International Arbitration' in (1997) $14 J$ Int.'l Arb. at pp. 39-66, 61-62, and Nathalie Voser, 'Mandatory Rules of Law as Limitation to the Iaw Applicable in International Commercial Arbitration' in (1996) 7 American Review of International Arbitration 3/4 at pp. 345-354; the arbitral tribunal can also take guidance from Art. 19 PILA and from Art. 7(1) of the 1980 Rome Convention. 
above-mentioned rules) there are mandatory rules of other states which require consideration. ${ }^{93}$

In 1976, in the famous Hirsch v. Cohen ${ }^{94}$ case, the Swiss Federal Supreme Court had to rule on the following issue: Mr Cohen had English nationality but had lived in Switzerland for 20 years prior to his death. By mean of professio iuris, the deceased submitted his estate to English law, and his second wife was appointed as sole heir. His daughter from his first marriage, who was also living in Switzerland, contested the validity of the will and requested that she receive as a minimum the compulsory portions of the estate in accordance with Swiss law. The Federal Supreme Court held that the compulsory portions were not part of the Swiss ordre public even if the professio iuris implied that an heir would receive nothing from the estate. ${ }^{95}$

Although outside the context of professio iuris the question is less pressing, it remains an issue, since it is generally recognized today that truly international mandatory rules ('Eingriffsnormen') operate as an 'adjustment' in the context of the choice of law by the tribunals and as a limitation to the choice of law by the parties. The above ruling of the Federal Supreme Court regarding indefeasible interest fits in with a restrictive interpretation of the mandatory rules; such rules should go beyond purely individual interests. ${ }^{96}$ As a result, once the CRT has determined the applicable law in accordance with the above-mentioned rules, it will not have to consider mandatory portions of the laws of habitual residence or of the country of which the claimants are nationals by means of a special connection ('Sonderanknüpfung'). ${ }^{97}$

It has been maintained that unworthiness to inherit based on conduct, in accordance with Article 540 of the Swiss Civil Code, qualifies as a mandatory rule under Article 18 PILA. ${ }^{98}$ Quite apart from the fact that in the context of the CRT it is unlikely that this could become relevant, there is no justifiable reason for the CRT (which, like any arbitral tribunal, lacks a lex forl) to treat this provision as a mandatory rule, since it does not fall into the narrow category of international mandatory rules ('Eingriffsnormen').

Mandatory Swiss law must be applied by the courts according to Art. 18 PILA. However, since an international arbitral tribunal has no lex fori, and Art. 18 PILA is not part of the lex arbitri the mandatory law of Switzerland does not have a paramount position. For an opposing point of view see Monica Mächler-Erne, Kommentar zum Schweizerischen Privatrecht - Internationales Privatrecht (1996) n. 20, Art. 18.

94 BGE 102 II 136 et seq.

95 BGE 102 II 141.

96 Voser, supra n. 92 at pp. 348-354.

97 This is also the rule under the Convention in Art. 7(2)(d).

98 Andreas Bucher, Droit international privé suisse, Vol. II (1992), note 987. 
(c) Relationship Between the Published Holder of a Power of Attorney and the Claimant

(i) Claims against holders of a power of attorney

The published lists of July and October 1997 contained not only names of account holders of published accounts but also names of holders of powers of attorney. So far, the percentage of claims with respect to power of attorney holders has been low. ${ }^{99}$

In the context of World War II, powers of attorney for account holders of accounts with Swiss banks had two possible functions:

(1) Proxy situation 1: the account holder was the legal and beneficial owner but instructed a representative to manage his or her account because the account holder - due to the war - was not able to do so himself or herself. For this purpose, the account holder granted a power of attorney to a representative to instruct the bank on his or her behalf; or

(2) Proxy situation 2: the power of attorney holder was, in reality, the beneficial owner, but in order to protect his or her assets from confiscation, did not present himself/herself as the legal owner but 'only' as the power of attorney holder. ${ }^{100}$

In proxy situation 1, a claimant can have a claim against the holder of a power of attorney based on the fact that the power of attorney holder misused his or her power of attorney and withdrew funds inappropriately from the account. Under Swiss law this would constitute a breach of the implicit or explicit fiduciary agreement between the account holder and the power of attorney holder. A claimant in this situation would have to claim that he or she was the rightful heir of the account holder - to be determined in accordance with the guidelines established above and that the account holder had a personal (or obligatory) right vis-à-vis the holder of the power of attorney (or his inheritance estate) based on the fiduciary agreement between the account holder and the power of attorney holder, and/or based on the unlawful conduct of the power of attorney holder (tort). In principle, the defendant in such a proceeding is not the bank, but the holder of the power of attorney (or his/her estate). However, if the bank participated in illegally misusing entrusted assets, a joint claim against the holder of the power of attorney and the bank might ensue. In practice, it is unlikely that such cases will come before the CRT; so far, none have. It is questionable whether the CRT would have jurisdiction for such claims, since such claims against a bank are not for specific assets forming part of a published dormant account.

In the second of the above-mentioned situations (proxy situation 2), both the standing of the bank as an opposing party to the claimant and the jurisdiction of

99 Until November 1998, less than 1 per cent.

100 Art. 1 para. (ii) RP provides that the CRT also has jurisdiction in such cases if the account was opened by a Swiss national 'if and to the extent a Sole Arbitrator determines, after consultation with ICEP, that such accounts may have been held by a Swiss intermediary for a victim of Nazi persecution'. 
the CRT are clearer, since the claimant's allegation would be that the assets still in the account actually belonged to the holder of the power of attorney and not to the legal owner, i.e. the (formal) account holder. Again, under Swiss law the agreement concluded between the account holder and the power of attorney holder would constitute an explicit or implicit fiduciary agreement between the account holder and the holder of the power of attorney, whereby the account holder would receive exceeding powers (i.e. he or she could, vis-à-vis third parties, legally do more than would be allowed under the trust agreement). Other than in the first case, the claimant's claim would be based on him or her being the rightful heir of the power of attorney holder, according to the applicable inheritance rules, and on a fiduciary agreement between the account holder and the power of attorney holder, under which agreement it would be determined that the power of attorney holder was the beneficial owner of the assets in the account.

\section{(ii) Applicable law}

According to Article $16 \mathrm{RP}$, the closest connection test is not only relevant for the relationship between the account holder and the claimant(s), but also for the relationship between the holder of a power of attorney and the claimant(s). In proxy situation 2, where the power of attorney holder was, in reality, the beneficial owner, the relevant considerations for the claimant's entitlement to the assets are exactly the same as for claims against published account holders. The only difference is that the relevant deceased person in this situation is not the account holder, but the power of attorney holder.

The wording of Article 16 paragraph 1 RP implies that the closest connection test applies only to the relationship between the account holder or power of attorney holder on the one hand, and the claimant(s) on the other. However, Article 16 paragraph $1 \mathrm{RP}$ also mentions (in brackets) fiduciary agreements. It is impossible to imagine how the account holder or the power of attorney holder, on the one hand, and the claimant on the other, could possibly have concluded a fiduciary agreement. This relationship will always be determined by means of inheritance considerations. It is, therefore, very likely that the intention of the authors of the first sentence of Article 16 paragraph 1 RP was also to submit the fiduciary agreement between the account holder and the power of attorney holder to the closest connection test, and that, therefore, the closest connection test applies not only to the relationship between the account holder or power of attorney holder on the one hand and the claimant on the other, but also to the relationship between the account holder and the power of attorney holder. Without this interpretation, the explicit reference to 'fiduciary agreements' does not mean anything as it stands. It should, therefore, be assumed that the closest connection test also applies to the relationship between the account holder and the power of attorney holder.

The claimant has entered into this relationship by means of inheritance, and therefore has either the rights of the account holder vis-à-vis the power of attorney holder (proxy situation 1), or the rights of the power of attorney holder vis-à-vis the 
account holder (proxy situation 2) or the respective heirs/estates. Because the basis of the fiduciary relationship was set when the account was opened, the CRT should examine the circumstances as they existed at the time when the fiduciary relationship was established in order to determine the closest connection in accordance with Article 16 RP.

Since there is a contractual relationship at stake, it is possible and justifiable to apply the criterion of performance of the characteristic obligation, which puts the closest connection in concrete terms. According to this rule, the closest connection is deemed to exist with the state of habitual residence of the party who must perform the obligation in question or, if a contract is entered into in the course of professional or business activities, with the state of the party's place of business. ${ }^{101}$ It is recognized that in fiduciary agreements, it is the trustee who performs the characteristic obligation since he or she, similarly to a representative, carries out non-monetary obligations. ${ }^{102}$

The consequences for the two proxy situations are as follows:

(1) Proxy situation 1: the power of attorney holder is the trustee and a contractual obligation on the part of the account holder's heirs against the holder of the power of attorney (or the descendants) falls under the law at the habitual residence of the power of attorney holder at the time when the fiduciary agreement was concluded. Since it is unlikely that the bank would also be part of this agreement, the law applicable to any claim against the bank based on assisting in potentially unlawful acts would have to be determined independently.

(2) Proxy situation 2: in this situation, it is the account holder who is the trustee and the applicable law is that of the habitual residence of the account holder at the time when the fiduciary agreement with the power of attorney holder was concluded. In case of doubt, it can be assumed that this was the date of the opening of the bank account.

The CRT can determine that there is an even closer connection with another law. However, in the interests of conformity and predictability of the outcome, the CRT should not, in the author's opinion, diverge without valid reason from these basic generally recognized rules for determining the applicable law.

\section{(d) Relationship Between a Swiss Bank and an Account Holder/Claimant}

The relationship at stake is contractual in nature and the banking relationship was entered into between the deceased account holder and a Swiss bank. In most cases it consisted of ${ }^{103}$

101 Art. 117 para. 2 PILA.

102 See e.g. Amstutz, Vogt and Wang, Kommentar zum Schweizerischen Privatrecht - Internationales Privatrecht (1996), note 34 at Art. 117.

${ }^{103}$ This is based on the recommendations of the Panel of Experts on Interest, Fees and Other Charges (established by the Independent Claims Resolution Foundation) of 4 September 1998. 
- establishing a savings, time or demand deposit;

- concluding a contract for investments in equities and/or bonds;

- managing accounts; and/or

- renting a safe deposit box to the account holder.

In accordance with Article 16 paragraph 2 RP, the relationship between a Swiss bank and a claimant shall be governed by Swiss law. By signing the CRA, and by submitting their claims to the CRT, the claimants have, therefore, made a choice of Swiss law by means of reference to the Rules of Procedure to which the CRA refers. Although the original contract was entered into by account holder, the claimants have - if recognized as being entitled to the account in accordance with the applicable law - eo ipso entered into the contractual relationship, and can choose the law to apply to a contract that was concluded long ago.

Under Swiss law, the choice of law by means of reference is valid, since the choice of law does not require any formalities, and can also be assumed from the circumstances. ${ }^{104}$ According to Article 187 PILA, an arbitral tribunal with its seat in Switzerland must respect the parties' choice of law, and can determine the applicable law only in the absence of a choice of law.

It should be noted that the choice of Swiss law corresponds to the law which would, as a rule, be applied by the Swiss courts based on the PII.A. According to the principle of performance of the characteristic obligation, the law in effect at the business location of the bank is applicable since the duties of the banks in the contractual relationships mentioned above constitute the characteristic obligation: although the banking relationship between the account holder and the bank usually has mixed status (i.e. cannot clearly be qualified as a contract provided by the law of obligations), safekeeping assets, managing accounts with bonds and/or equities investments, and establishing deposits are generally recognized as constituting the characteristic obligations.

In exceptional circumstances, the account holder and the Swiss bank might have made a choice of law at the time when the banking relationship commenced. This choice does not prevent parties to today's proceedings from choosing Swiss law by reference to the RP in the CRA since, based on the general principle of conflict of laws, the choice of the applicable law may be made and changed at any time by the parties. If this choice is agreed upon or altered after the conclusion of the contract, the choice will have a retroactive effect as of the time of entering into the contract. ${ }^{105}$

\footnotetext{
${ }^{104}$ Art. 116 para. 2 PILA.

${ }^{10.5}$ Art. 116 para. 3 PILA.
} 


\section{CHOICE OF LAW AND AUTHORIZATION BY THE PARTIES TO DECIDE EX AEQUO ET BONO}

\section{(a) Relationship Between the Account Holder/Power of Attorney Holder and the Claimant}

Since there are no provisions covering the mandatory character of specific RP rules, there is no reason why the parties cannot agree to the CRT applying a law other than that provided for in the RP, i.e. the law which the CRT determines to be in accordance with the principle of closest connection; within the limits of mandatory provisions (in the sense of 'Eingriffsnormen') the CRT should respect this choice of law.

As explained above, the author suggests the application of the conflict-of-laws rules of the state of the last domicile of account holders who died as a consequence of World War II (third category), which, most often, leads to the law of the nationality of the account holder. In situations where all the claimants come from jurisdictions applying the principle of domicile, a mutual agreement to choose this law can be reached. The bank should not refuse to agree to this choice, since it should not interfere in the mechanism of allocating the assets to the entitled claimants. This might account for why Article 16 paragraph 1 RP explicitly allows the involved parties to request the application of talmudic law to inheritance matters, and why the CRT must apply this law independently of whether or not the Swiss bank consented to it.

\section{(b) Relationship Between the Claimant and the Swiss Bank}

Since the RP already provides the choice of Swiss law for the relationship between the claimant and the Swiss bank, a question which might arise is whether or not the claimants and the Swiss bank can choose a law other than Swiss. Again, it can be assumed that the RP does not require the mandatory application of specific provisions. Therefore, there is no reason to prevent the parties from choosing a law other than Swiss law, after the claim has been submitted to the CRT.

\section{(c) Decision ex aequo et bono}

According to Article 187 PILA, the parties may authorize the arbitral tribunal to decide ex aequo et bono. In international arbitration, the authorization to decide according to equitable consideration mainly implies an authorization to decide according to transnational legal principles and international trade customs, i.e. the arbitral tribunal can decide on the basis of equitable considerations without making a decision on the question of which law is applicable. ${ }^{106}$ In this situation,

\footnotetext{
${ }^{106}$ Karrer, supra n. 31, note 187, Art. 187. An opposing opinion maintains that the ex aequo et bono decision does not discharge the arbitral tribunal from choosing the applicable law but only grants the discretion to correct the result found under the lex causae. This is the solution of the amiable compositeur under French law.
} 
the arbitral tribunal is only bound by public policy. ${ }^{107}$ This means - as currently understood - by the transnational mandatory rules. ${ }^{108}$

There is a distinction to be made in Switzerland between deciding ex aequo et bono and the amiable composition. The amiable compositeur, who comes from French law, determines the applicable law and then makes the adjustments to the outcome of the case which he or she deems necessary. An arbitral tribunal acting in amiable composition is not only limited by the international mandatory rules, but also by the internal mandatory rules of the applicable law. ${ }^{109}$ Since the parties can allow the arbitral tribunal to act ex aequo et bono, they can also allow the tribunal to act as amiable compositeur, which, according to the above definition, is less far-reaching. ${ }^{110}$

If an arbitral tribunal decides ex aequo et bono without being authorized by the parties to do so, its award may be challenged on the grounds that the arbitral tribunal has exceeded its authority. It is, therefore, important to respect any form requirements for the authorization to decide ex aequo et bono. Whether or not an express authorization is necessary is a matter of dispute among Swiss scholars. Since the provision in Article 187 paragraph 3 PILA was made in the context of the choice of law, and since it is recognized that a choice of law can be made implicitly by the parties, it must be assumed that the parties can also implicitly authorize the arbitral tribunal to render an ex aequo et bono decision. ${ }^{111}$ In any event, since the circumstances which would allow one to assume such implied authorization are difficult to determine, it is advisable to request an express authorization from the parties.

There are different situations where it would be advisable for the parties to give the CRT the authorization to render an award based on ex aequo et bono. This is the case when the nationality of an account holder who died during the war (first category) cannot be determined, or (for categories two and three) when the location of the account holder's habitual residence over the last five years of his or her life cannot be determined, or when two generations died during the war, and the sequence of the deaths cannot be established. From the point of view of the claimants, it might be useful to authorize the CRT to render an ex aequo et bono award in situations where the claimants are not willing to conclude a settlement agreement, but would nevertheless like to emphasize the concept of equitable consideration, as opposed to that of finding the applicable law.

\footnotetext{
107 Bucher and Tschanz, Die neue internationale Schiedsgerichtbarkeit in der Schweiz, (1989) note 315.

108 See supra II (c).

109 Karrer, supra n. 31, note 191, Art. 187. Bucher and Tschanz, supra n. 107, note 120.

110 Bucher and Tschanz, supra n. 107 , note 318.

111 Karrer, supra n. 31, note 198, Art. 187.
} 


\section{SUMMARY}

Inheritance disputes among several heirs are, in principle, arbitrable, since under the Swiss lex arbitri the decisive issue for the determination of arbitrability is whether or not the dispute involves an economic interest. The Swiss Federal Supreme Court has decided that this principle is only limited if foreign rules providing for exclusive state jurisdiction are of public policy character.

The RP does not prevent the parties from making their own choice of applicable law. With regard to the relationship between the published account holder and the claimant(s), and in the absence of a choice of law by the parties, the $\mathrm{RP}$ provides for the application of the law which has the closest connection to the matter in dispute. An overview of conflict-of-law solutions used by state courts has revealed that this relationship should be determined in accordance with the law of the state to which the account holder had the closest connection at the time of his or her death. In view of the conflict-of-law solutions' consistent emphasis on the situation of the deceased at the time of death, it cannot be assumed that contractual obligations with a Swiss bank and/or movable assets located in Switzerland constitute a sufficient connection to Switzerland to justify the application of Swiss law. In an attempt to establish guidelines for the interpretation of the closest connection, it has been suggested that the claims be divided into three main categories. It is justified to resolve (1) claims unrelated to World War II, and (2) claims with regard to account holders who emigrated or had to flee because of World War II (but died later) in accordance with the Hague Convention on the Law Applicable to Succession to the Estates of Deceased Persons adopted in 1988. However, for (3), victims of World War II, it would seem more justified to apply the law as it would have been applied at the time and place of their death. In the event of a death after deportation, it must be assumed that the relevant place was the place where the account holder lived permanently before being deported.

The closest connection test with regard to the relationship between power of attorney holders and claimant(s) in claims against a holder of a power of attorney is identical to the test applied to the relationship between account holders and claimant(s) in claims against account holders.

Although not clearly expressed in Article 16 paragraph $1 \mathrm{RP}$, the closest connection test also applies to fiduciary agreements between the account holder and the power of attorney holder where the former was 'only' a trustee and the power of attorney holder, in reality, was the beneficial owner. In this situation, the test leads to the application of the law in effect at the habitual residence of the account holder at the time of the conclusion of the fiduciary agreement with the power of attorney holder.

Article 16 paragraph 2 RP provides that the relationship between the claimant and the Swiss bank shall be governed by Swiss law. This is the same solution as would be reached by applying the Swiss conflict-of-law rules.

According to the Swiss lex arbitri the parties to the Claims Resolution Process can authorize the CRT to decide ex aequo et bono. The CRT, by means of this authorization, can decide on the basis of equitable considerations without making 
a decision on the question of which law is applicable. It might be useful, especially in complex multiparty situations, to grant the CRT this authorization, in order to minimize the time until the assets in the dormant accounts can finally be paid to the rightful heirs. 